\title{
Occurrence of Akodon cursor (Rodentia, Cricetidae) with 14, 15 and 16 chromosome cytotypes in the same geographic area in Southern Brazil
}

\author{
Ives José Sbalqueiro and André Paulo Nascimento
}

\begin{abstract}
The karyotype of Akodon cursor (initially identified as A. arviculoides) had been reported with chromosomal numbers 14 and 15 in the South and Southeast and 16 in Northeastern Brazil. We found the three cytotypes in a region of Southern Brazil. The G-band patterns of these specimens were the same as those from southeastern and northeastern regions. Seventeen different combinations of chromosomes due to a complex rearrangement in pair 1 and pericentric inversions in pairs 2 and 3 were identified. Seven of these combinations are new to in the literature.
\end{abstract}

\section{INTRODUCTION}

Akodon is widely distributed throughout South America, except for the lowlands of the Amazon basin (Myers and Patton, 1989). This genus includes species very similar in morphology, some of them difficult to separate taxonomically, although there is considerable karyotypic diversity $(2 n=14$ to 52$)$. The intraspecific and intrapopulational chromosomal variations are due to structural and numerical rearrangements. Centric fusion in Akodon has been found by Bianchi et al. (1969, $1971,1973)$ in A. molinae ( $2 \mathrm{n}=42$ to 44$)$; Bianchi et al. (1971, 1979) and Kiblisky et al. (1976) in A. dolores (2n = 34 to 40); and Yonenaga-Yassuda et al. (1987) in $A$. reinhardti $(2 \mathrm{n}=37,38)$.

In A. cursor the diploid numbers 14 and 15 have been found in Paraná (Bossle et al., 1988), São Paulo (Yonenaga, 1972; Yonenaga et al., 1975 and Yonenaga-

Departamento de Genética, Setor de Ciências Biológicas, Uni3versidade Federal do Paraná, Caixa Postal 19071, 81531-990 Curitiba, PR, Brasil. E-mail: ivesjs@bio.ufpr.br. Send correspondence to I.J.S.
Yassuda et al., 1983) and Rio de Janeiro (YonenagaYassuda, 1979) and 16 in Pernambuco (Maia and Langguth, 1981). These differences are due to complex rearrangements comprising centric fission-fusion and pericentic and paracentric inversions. Changes in the number of autosomal arms produced by pericentric inversions occur in three autosomal pairs (Yonenaga, 1972; Yonenaga et al., 1975; Yonenaga-Yassuda, 1979; Maia and Langguth, 1981; Yonenaga-Yassuda et al., 1983; Bossle et al., 1988).

\section{MATERIAL AND METHODS}

A total of 97 specimens of $A$. cursor (55 males and 42 females) were collected from different localities of Guaraqueçaba Bay in Paraná State, Southern Brazil $\left(25^{\circ} 15^{\prime} \mathrm{S}\right.$ and $\left.48^{\circ} 30^{\prime} \mathrm{W}\right)$. They were taken from four islands (Rabelo, Rasa, Laranjeiras and Gamelas) and three localities on the mainland (Tromomô, Laranjeiras and Massarapuã) (Figure 1a). The specimens were 
prepared as standard museum skins and skulls and the voucher specimens are in the collection of the Departamento de Genética, Universidade Federal do Paraná, Curitiba, Brazil. Chromosomes were obtained from bone marrow by using Ford and Hamerton's (1956) technique. G-banding was obtained by trypsin treatment (Seabright, 1971, with modifications). Chromosome nomenclature used in this paper is that used by Yonenaga-Yassuda (1979).

\section{RESULTS}

Forty-nine animals (29 males and 20 females) had $2 n=14$ and NA (number of autosomal arms) ranging from 18 to $21 ; 22$ males and 22 females had $2 n=15$ and $N A=20$ to 24 , and four males had $2 \mathrm{n}=16$ and $\mathrm{NA}=$ 23,24 . The $2 \mathrm{n}=14$ forms (Figure 2A) had a pair 1 with two large metacentric chromosomes; pair 2 comprised two medium-sized submetacentrics and/or acrocentrics; pair 3 had mediumsized acrocentrics and/or metacentrics; pair 4 were medium-sized metacentrics; pair 5, medium-sized acrocentrics, and pair 6 , minute metacentrics. The sex-chromosome pair had two acrocentric homomorphic $X_{S}$ in females, and two heteromorphic acrocentrics in $X Y$ males; the $Y$ chromosome being similar in size to pair 6 .

Chromosomal poly. morphisms were detected in pairs 2 and 3 and were due to pericentric inversions. The 21 different karyotypes so far reported in $A$. cursor are shown in Table I. Seventeen were found in Guaraqueçaba, seven of which had not been previously reported by other authors. The ten karyotypes found in Guaraqueçaba and in other regions were: $A, B, C, D, E, G, I, J, L$, and $M$. The seven

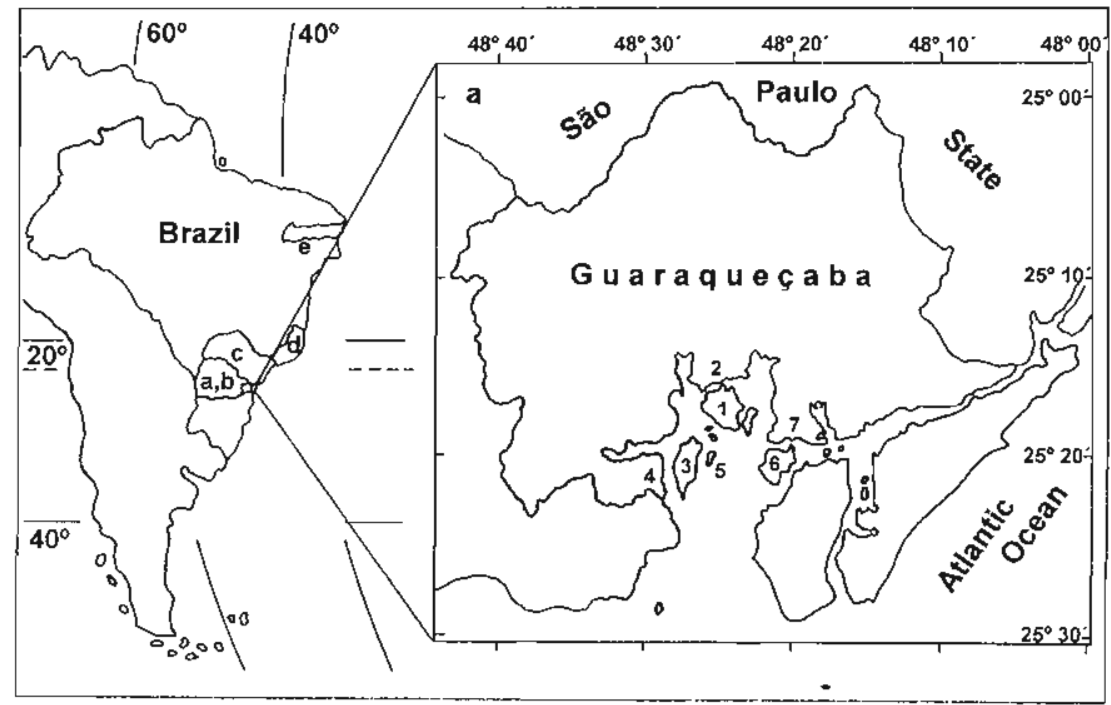

Figure 1 - Map of South America showing Brazilian distribution of karyotypic forms of Akodon cursor: a) Paraná - Guaraqueçaba with capture points studied in this investigation: 1, Rabelo island $(2 \mathrm{n}=14,15)$; 2 , Tromomô $(2 \mathrm{n}=14,15,16) ; 3$, Rasa island $(2 \mathrm{n}=14,15,16)$; 4, Massarapuã $(2 n=14,15,16) ; 5$, Gamelas island $(2 n=14,15) ; 6$, Laranjeiras island $(2 n=$ $14,15) ; 7$, Laranjeiras mainland $(2 \mathrm{n}=14,15)$; b) Paraná - Serra do Mar $(2 \mathrm{n}=14,15)$; c) São Paulo $(2 n=14,15)$; d) Rio de Janeiro $(2 n=14,15)$; e) Pernambuco $(2 n=16)$.

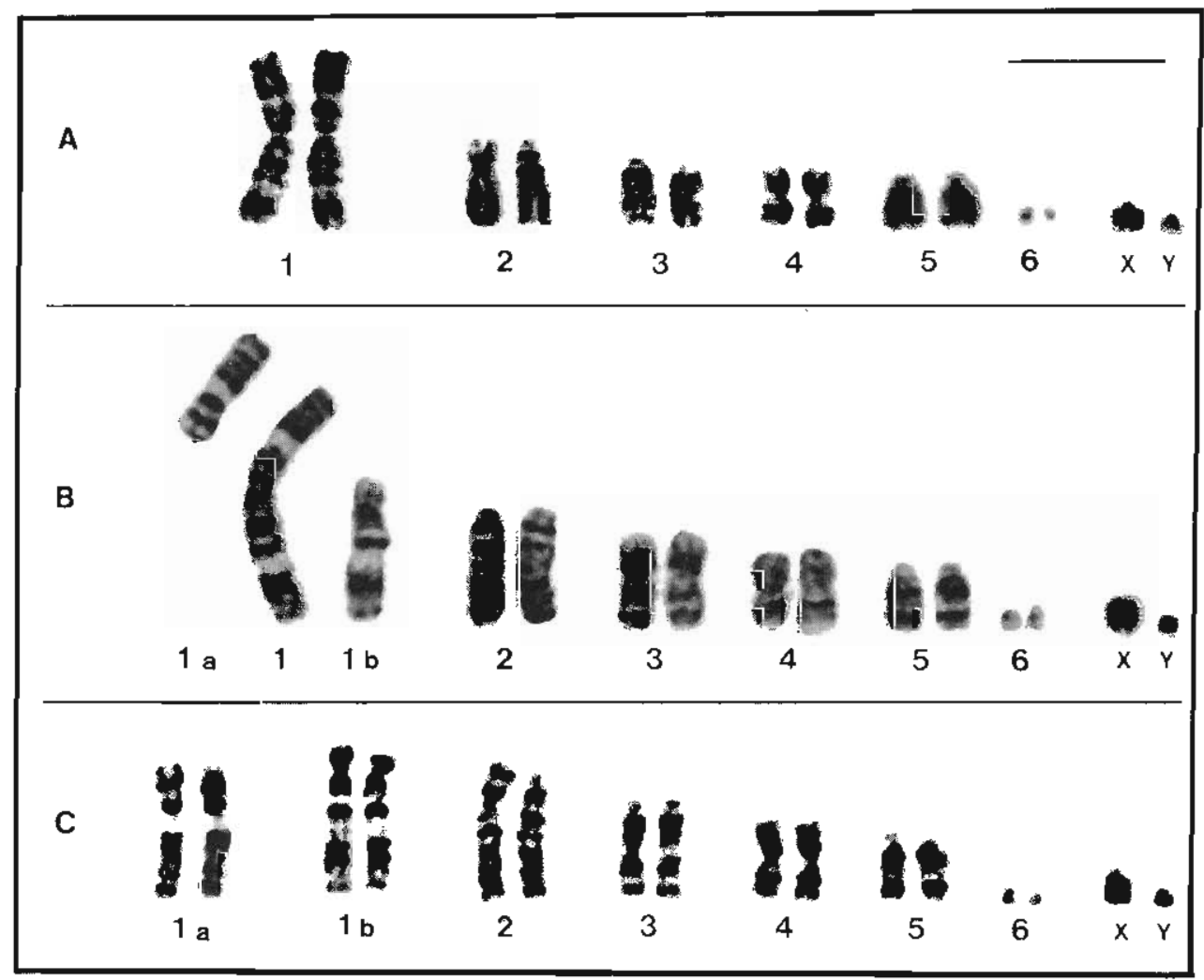

Figure 2 - G-band patterns of cytotypes of $A k v d o n$ cursor. A) $2 n=14, N A=19$, chromosome 1 in homozygosis, pair 2 heterozygous, pair 3 homozygous for acrocentric form; $B$ ) $2 n=15, N A=22$, the unique chromosomes $1,1 \mathrm{a}$ and $1 \mathrm{~b}$, pair 2 homozygous for acrocentric form, pair 3 homozygous for metacentric form; C) $2 n=16, N A=23$, chromosomes $1 \mathrm{a}$ and $1 \mathrm{~b}$ in homozygosis, pair 2 heterozygous, pair 3 homozygous for acrocentric form. Bar $=10 \mu \mathrm{m}$. karyotypes found only in Guaraqueçaba were: $\mathrm{F}, \mathrm{N}, \mathrm{O}$, $P, Q, R$, and $S$. In pair 2 , we detected $53 \%$ of specimens homozygous for the acrocentric form, $43 \%$ 
Table I - Karyotypes described for Akodon cursor.

\begin{tabular}{|c|c|c|c|c|c|c|c|}
\hline Karyotype & $2 n$ & NA & $\begin{array}{c}\text { Pair }^{1} \\
2\end{array}$ & $\begin{array}{c}\text { Pair }^{1} \\
3\end{array}$ & $\begin{array}{l}\text { Specimens } \\
\text { studied }^{2}\end{array}$ & $\begin{array}{l}\text { Locality }^{3} \\
\text { (States) }\end{array}$ & References \\
\hline A & 14 & 18 & A & A & $16(2 ; 3)$ & SP, RJ, PR & $\begin{array}{l}\text { Yonenaga, 1972; Yonenaga et al., 1975; } \\
\text { Yonenaga-Yassuda, 1979; Yonenaga- } \\
\text { Yassuda et al., 1983; Fagundes, 1993; } \\
\text { this study }\end{array}$ \\
\hline B & 14 & 19 & A & $\mathrm{H}$ & $45(9 ; 8)$ & SP, RJ, PR & $\begin{array}{l}\text { Yonenaga, 1972; Yonenaga et al., 1975; } \\
\text { Yonenaga-Yassuda, 1979; Yonenaga- } \\
\text { Yassuda et al., 1983; Fagundes, 1993; } \\
\text { this study }\end{array}$ \\
\hline C & 14 & 19 & $\mathrm{H}$ & A & $12(2 ; 1)$ & SP, RJ, PR & $\begin{array}{l}\text { Yonenaga, 1972; Yonenaga et al., 1975; } \\
\text { Yonenaga-Yassuda, 1979; Yonenaga- } \\
\text { Yassuda et al., 1983; Fagundes, 1993; } \\
\text { this study }\end{array}$ \\
\hline $\mathrm{D}$ & 14 & 20 & A & M & $13(2 ; 3)$ & $\mathrm{SP}, \mathrm{PR}$ & $\begin{array}{l}\text { Yonenaga, 1972; Yonenaga et al., 1975; } \\
\text { Fagundes, 1993; this study }\end{array}$ \\
\hline $\mathrm{E}$ & 14 & 20 & $\mathrm{H}$ & $\mathrm{H}$ & $18(4 ; 4)$ & SP, RJ, PR & $\begin{array}{l}\text { Yonenaga et al., 1975; Yonenaga- } \\
\text { Yassuda, 1979; Yonenaga-Yassuda et al., } \\
\text { 1983; Fagundes, 1993; this study }\end{array}$ \\
\hline $\mathrm{F}$ & 14 & 20 & SM & A & $2(1 ; 1)$ & PR & This study \\
\hline G & 14 & 21 & $\mathrm{H}$ & M & 10 (9 males) & SP, PR & $\begin{array}{l}\text { Yonenaga-Yassuda et al., 1983; } \\
\text { this study }\end{array}$ \\
\hline $\mathrm{H}$ & 14 & 21 & $\mathrm{SM}$ & $\mathrm{H}$ & 1 & $\mathrm{SP}$ & Yonenaga et al., 1975 \\
\hline I & 15 & 20 & A & A & $6(2 ; 3)$ & SP, PR & Fagundes, 1993; this study \\
\hline $\mathrm{J}$ & 15 & 21 & A & $\mathrm{H}$ & $12(4 ; 6)$ & SP, PR & $\begin{array}{l}\text { Yonenaga-Yassuda, 1979; Fagundes, } \\
\text { 1993; this study }\end{array}$ \\
\hline $\mathrm{K}$ & 15 & 21 & $\mathrm{H}$ & A & 1 & SP & Fagundes, 1993 \\
\hline $\mathrm{L}$ & 15 & 22 & A & M & $9(5 ; 3)$ & SP, PR & Yonenaga-Yassuda, 1979; this study \\
\hline M & 15 & 22 & $\mathrm{H}$ & $\mathrm{H}$ & $15(7 ; 7)$ & SP, PR & Yonenaga-Yassuda, 1979; this study \\
\hline $\mathrm{N}$ & 15 & 23 & $\mathrm{H}$ & M & $5(3 ; 2)$ & PR & This study \\
\hline $\mathrm{O}$ & 15 & 23 & SM & $\mathrm{H}$ & 1 (male) & PR & This study \\
\hline $\mathrm{P}$ & 15 & 24 & SM & M & 1 (female) & $P R$ & This study \\
\hline$Q$ & 16 & 23 & A & $\mathrm{H}$ & 1 (male) & PR & This study \\
\hline $\mathrm{R}$ & 16 & 23 & $\mathrm{H}$ & A & 2 (males) & PR & This study \\
\hline $\mathrm{S}$ & 16 & 24 & $\mathrm{H}$ & $\mathrm{H}$ & 1 (male) & PR & This study \\
\hline $\mathrm{T}$ & 16 & 25 & $\mathrm{SM}$ & $\mathrm{H}$ & 2 & PE & Maia and Langguth, 1981 \\
\hline $\mathrm{U}$ & 16 & 26 & SM & M & 23 & PE & Maia and Langguth, 1981 \\
\hline
\end{tabular}

NA = Number of autosomal arms.

${ }^{1} \mathrm{~A}=$ Acrocentric; $\mathrm{H}=$ heterozygous; $\mathrm{M}=$ metacentric; $\mathrm{SM}=$ submetacentric.

${ }^{2}$ The number of males and females, respectively, from Guaraqueçaba (PR) are shown within parentheses.

${ }^{3} \mathrm{SP}=$ São Paulo; RJ = Rio de Janeiro; PR = Paraná; PE = Pernambuco.

heterozygous, and $4 \%$ homozygous for the submetacentric form. Pair 3 showed 17\% homozygous for acrocentrics, $54 \%$ heterozygous, and $29 \%$ metacentrics in homozygosis. Both pairs were in Hardy-Weinberg equilibrium (pair 2: $\chi_{(2)}^{2}=0.0174$; pair 3: $\left.\chi_{(2)}^{2}=0.0075 ; \mathrm{P}>0.99\right)$.

All kinds of possible combinations considering pairs 2 and 3 were found in Guaraqueçaba (PR). The homozygous acrocentric pair 2 associated with heterozygous pair 3 were the most frequent combination. Homozygous for submetacentric in pair 2 with homozygous for metacentric or heterozygous in pair 3 were the two rarest combinations.

The numerical differences among the three cytotypes are due to a complex rearrangement involving centric fusion-fission in the chromosomes of pair 1 . Specimens with $2 \mathrm{n}=14$ (Figure $2 \mathrm{~A}$ ) showed two metacentric chromosomes 1 . In $2 n=15$ (Figure 2B) there are three elements: a large metacentric (1) and two different submetacentrics ( $1 \mathrm{a}$ and $1 \mathrm{~b}$ ), while in $2 \mathrm{n}=16$ (Figure $2 \mathrm{C}$ ) pair 1 is substituted by pairs $1 \mathrm{a}$ and $1 \mathrm{~b}$ in the homozygous state. G-banding shows that $1 \mathrm{a}$ and $1 \mathrm{~b}$ 
have homology with the short and long arms of pair 1, and G-band patterns also show an inversion when $1 \mathrm{a}$ is compared to the short arm of chromosome 1 (Figure 2B). In three of the seven localities studied (Figure 1a) (Rasa island, Tromomô and Massarapuã) we observed the three cytotypes.

\section{DISCUSSION}

Comparative analysis of G-band patterns among the three cytotypes found in this study with those described for southern (Figure 1b; Bossle et al., 1988), southeastern (Figure 1c; Yonenaga, 1972 and Figure 1d; Yonenaga-Yassuda, 1979) and northeastern regions (Figure 1e; Maia and Langguth, 1981) shows homologies among all chromosomal pairs.

Cytogenetic studies of $A$. cursor from different regions of Brazil (Table I) demonstrate geographic variation in diploid number and a remarkable chromosomal polymorphism, due to a high frequency of pericentric inversions involving pairs 2 and 3 . Chromosomal variation in pair 5 was observed only in a female from Rio de Janeiro State studied by Yonenaga-Yassuda (1979). The high frequency of heterozygosity for pairs 2 and 3 was also reported by Yonenaga (1972), Yonenaga et al. (1975), Yonenaga-Yassuda (1979), Yonenaga-Yassuda et al. (1983), Bossle et al. (1988), and Fagundes (1993). Maia and Langguth (1981) studied specimens with $2 \mathrm{n}=16$ from Pernambuco State. They did not find the acrocentric chromosome form in pair 2. Twentyseven karyotypes are expected, considering the possible combinations among all chromosome forms of pairs 1, 2 , and 3 . As the pericentric inversion in pair 5 is unusual it was disregarded as a possible source of karyotype variation. Twenty-one karyotypes for $A$. cursor have been described so far, and six karyotypes remain to be found. The polymorphisms in pairs 2 and 3 of our sample were in Hardy-Weinberg equilibrium. This high frequency of heterozygotes does not seem to reduce fertility in this species.

White (1978) postulated that chromosomal rearrangements play an important role in initiating divergence during speciation. They may reduce the viability of embryos or, if they do not depress viability, they may produce meiotic arrest. King (1987, 1993) considers chromosomal rearrangements as post-mating isolating mechanisms; yet this author proposes that different kinds of events may occur in the meiosis of some Rodentia species, nullifying the deletereous effect of heterozygosis for pericentric inversions. Centric fusion and pericentric inversion are potentially negative in heterozygous specimens. Once the aneuploid gametes are produced, rearrangements could even decrease the viability of the individuals. However, this seems not to occur because many heterozygotes can be observed in A. cursor from Guaraqueçaba and other localities. Fagundes (1993) found A. cursor males of São Paulo State with normal meiosis, probably due to the existence of heterosynapsis in regions with pericentric inversion. This can represent a heterotic condition, with increased fitness of the heterozygotes compared to homozygotes. For White (1978), both heterosis and frequency-dependent selection could lead to the polymorphic state of a rearrangement. White (1978) also suggested that chromosomal rearrangements existing in a balanced polymorphic state are more likely to be cohesive than divisive agents in natural populations. King (1993) argue that chromosomal polymorphisms with a high frequency of heterozygosis - as we observe in A. cursor - could not be associated with speciation.

In the south (Bossle et al., 1988) and southeast (Yonenaga, 1972 and Yonenaga-Yassuda, 1979) specimens with 14 and 15 chromosomes are frequent while $2 n=16$ specimens are found in the northeast (Maia and Langguth, 1981). We found specimens with 14,15 and 16 chromosomes in the same geographic area in three out of seven localities of Guaraqueçaba Bay. Moreover, in our series pericentric inversions were only found in pairs 2 and 3. Bossle et al. (1988) in a study of seven specimens $(2 \mathrm{n}=14,15)$ collected from Serra do Mar (Antonina City, Paraná State) also observed pericentric inversions only in chromosomes 2 and 3.

Sbalqueiro, I.J. and Nascimento, A.P., unpublished results, were able to obtain specimens under laboratory conditions with 14, 15 and 16 chromosomes from crosses of specimens with $2 n=15$. This supports the assumption that a similar phenomenon may occur in wild populations of $A$. cursor.

The submetacentric form in pair 2 was found in all places where the species was studied, but the acrocentric form was not observed in Pernambuco. The heterozygosity of pair 3 was detected in specimens from all the localities so far assessed; however, acrocentric and metacentric homozygous forms have not yet been found in Pernambuco and Rio de Janeiro, respectively.

According to Yonenaga-Yassuda (1979) the polymorphism detected in pair 1 of this species can be explained by two alternative mechanisms: a) pericentric inversions in submetacentrics $1 \mathrm{a}$ and $1 \mathrm{~b}$ followed by centric fusion or b) chromosomal dissociation of the largest metacentric followed by pericentric inversion in the segment corresponding to the long arm, originating $1 \mathrm{~b}$ chromosome, and centromeric activation followed by paracentric inversion in the other segment, originating $1 \mathrm{a}$. 
Alfredo Langguth (personal communication in Fagundes, 1993) considers the northeastern specimens as a different species of $A$. cursor, suggesting the temporary denomination of $A$. aff. cursor. The occurrence of $2 n$ $=16$ in Guaraqueçaba does not support this suggestion, although it is not sufficient to discard it.

\section{ACKNOWLEDGMENTS}

We thank Luiz Cezar Machado Pereira for help with the field work. We acknowledge Eleidi A.C. Freire-Maia, Alexandre U. Christoff, Edivaldo H.C. Oliveira, Iglenir J. Cavalli, and Thales R.O. Freitas for critical reading and review of the manuscript. Research supported by Conselho Nacional de Desenvolvimento Científico e Tecnológico (CNPq) and Instituto Brasileiro do Meio Ambiente e Recursos Naturais Renováveis (IBAMA).

\section{RESUMO}

O cariótipo de Akodon cursor (inicialmente identificado como $A$. arviculoides) tinha sido relatado com números cromossômicos 14 e 15 no Sul e Sudeste do Brasil e 16 no Nordeste brasileiro. Neste trabalho é mostrado, pela primeira vez, a ocorrência conjunta das três formas cariotípicas, em três locais de coleta, na baía de Guaraqueçaba, região Sul do Brasil. Os padrões de bandamento $G$ do complemento cromossômico dos espécimens do Sul não mostram diferenças com relação aos padrões das regiões Sudeste e Nordeste. Foram identificadas 17 combinações cariotípicas diferentes devido a um rearranjo complexo no par 1 e a inversões pericêntricas nos pares 2 e 3 . Sete destas combinações ainda não tinham sido relatadas na literatura.

\section{REFERENCES}

Bianchi, N.O., Contreras, J.R. and Dulont, E.N. (1969). Intraspecies autosomal polymorphism and chromosome replication in Akodon molinae (Rodentia, Cricetidae). Can. J. Genet. Cytol. 11: 233-242.

Bianchi, N.O., Reig, O.A., Molina, O. and Dulont, E.N. (1971). Cytogenetics of the South American Akodon rodents (Cricetidae). I. A progress report of Argentinian and Venezuelan forms. Evolution 25: 724-736.

Bianchi, N.O., Vidal-Rioja, L. and Bianchi, M.S.A. (1973). Constitutive heterochromatin, G-bands and Robertsonian rearrangements in the chromosomes of Akodon molinae (Rodentia, Cricetidae). Can. J. Genet. Cytol. 15: 855-861.

Bianchi, N.O., Merani, S. and Lizarralde, M.S. (1979). Cytogenetics of the South American akodont rodents (Cricetidae). VI. Polymorphism in Akodon dolores (Thomas). Genetica 50: 99-104.
Bossle, R.C., Alzão, C.R., Beck, A.D., Sbalqueiro, I.J. and Lange, M.B.R. (1988). Estudos cromossômicos em dois gêneros de roedores da família Cricetidae coletados na Serra do Mar no Estado do Paraná. Resumos do XV Congresso Brasileiro de Zoologia, 521. Curitiba, 31 de janeiro a 05 de fevereiro de 1988, pp. 683.

Fagundes, V. (1993). Análises cromossômicas e dos complexos sinaptonêmicos em roedores brasileiros das famílias Cricetidae e Echimidae. Master's thesis, Universidade de São Paulo, São Paulo.

Ford, C.E. and Hamerton, J.L. (1956). A colchicine hypotonic citrate squash sequence for mammalian chromosomes. Stain. Tech. 31: 247-251.

Kiblisky, P., Merani, S., Molina, O. and Bianchi, N.O. (1976). Citogenética de los roedores sudamericanos akodontinos (Cricetidae). III. Polimorfismos cromossômicos intraespecíficos en Akodon dolores Thomas. Mendeliana 1: 97-103.

King, M. (1987). Chromosomal rearrangements, specification and the theoretical approach. Heredity 59: 1-6.

King, M. (1993). Species Evolution - the Role of Chromosome Change. Cambridge University Press, Cambridge, pp. 336.

Maia, V. and Langguth, A. (1981). Karyotypes of Brazilian Akodont rodents with notes on Taxonomy. Z. Säugetierk 46: 241-249.

Myers, P. and Patton, J.L. (1989). A new species of Akodon from the cloud forests of eastern Cochabamba Department, Bolivia (Rodentia: Sigmodontinae). Occas. Pap. Mus. Zool. 720: 1-28.

Seabright, M. (1971). A rapid banding technique for human chromosome. Lancet 2: 971-972.

White, M.J.D. (1978). Modes of Speciation. W.H. Freeman and Company, San Francisco, pp. 455.

Yonenaga, Y. (1972). Chromosomal polymorphisms in the rodent Akodon arviculoides ssp. $(2 \mathrm{n}=14)$ resulting from two pericentric inversions. Cytogenetics 11: 488-499.

Yonenaga, Y., Kasahara, S., Almeida, E.J.C. and Peracchi, A.L. (1975). Chromosomal banding patterns in Akodon arviculoides $(2 \mathrm{n}=14)$, Akodon sp $(2 \mathrm{n}=24$ and 25$)$, and two male hybrids with 19 chromosomes. Cytogenet. Cell Genet. 15: 388-399.

Yonenaga-Yassuda, Y. (1979). New karyotypes and somatic and germ-cell banding in Akodon arviculoides (Rodentia, Cricetidae). Cytogenet. Cell Genet. 23: 241-249.

Yonenaga-Yassuda, Y., Assis, M.F.L., Kasahara, S., L'Abbate, M. and Souza, M.J. (1983). Nucleolar organizer regions in Akodon arviculoides (Cricetidae, Rodentia): evidence for the activity of rDNA genes in both X chromosomes of females. Cytogenet. Cell Genet. 35: 143-147.

Yonenaga-Yassuda, Y., Pereira, L.A. and L'Abbate, M. (1987). Chromosomal polymorphism in Akodon reinhardti Langguth, 1975 (Rodentia, Cricetidae). Rev. Bras. Genet. 10: 199-208. 